\title{
Tradisi Musik Vokal Singiran Sebagai Media Pembelajaran Budi Pekerti pada Anak Santri di Jawa
}

\author{
Jarmani \\ Pendidikan Guru Sekolah Dasar, Fakultas Bahasa dan Sains, \\ Universitas Wijaya Kusuma Surabaya. \\ email: jarmani fbs@uwks.ac.id
}

\begin{abstract}
Singiran is one of the art of vocal music in the form of poetry sung through a song, whether in Arabic or Javanese, which is very well known in traditional Javanese Islam. This study uses a qualitative approach by applying research concepts that are in accordance with the conditions in the field, in this case qualitative research which becomes an instrument or research tool is the research itself. Data collection techniques using document studies and field studies, namely interviews and observation. From the results of data collection it turns out that singir has been neglected by the community, and it turns out that singir has a very meaningful function for its supporters, namely the use of a number of singers in the learning of children's character. With the view of the function of singir art, educators, especially art, should be even more creative in innovation about education through art media.
\end{abstract}

Keywords: singiran, learning media, student.

\begin{abstract}
Abstrak
Singiran merupakan salah satu seni musik vokal yang berbentuk syair yang dilantunkan melalui sebuah lagu, baik yang berbahasa Arab ataupun Jawa sangat dikenal luas di kalangan Islam tradisional Jawa. Penelitian ini menggunakan pendekatan kualitatif dengan menerapkan konsep penelitian yang sesuai dengan kondisi di lapangan, dalam hal ini penelitian kualitatif yang menjadi instrument atau alat penelitian adalah penelitian itu sendiri. Teknik pengumpulan data dengan menggunakan studi dokumen dan studi lapangan yaitu wawancara dan observasi. Dari hasil pengumpulan data singir ternyata mulai terabaikan dari masyarakat, dan ternyata singir mempunyai fungsi yang sangat bermakna bagi pendukungnya yaitu dimanfaatkannya sejumlah singir dalam pembelajaran budi pekerti anak. Dengan adanya pandangan terhadap fungsi kesenian singir seharusnya para pendidik khususnya seni harus lebih kreatif lagi dalam inovasi tentang pendidikan melalui media kesenian.
\end{abstract}

Kata kunci : singiran, media pembelajaran, santri. 
PENDAHULUAN

Masyarakat Jawa secara antropologis adalah orang-orang yang dalam hidup kesehariannya menggunakan bahasa Jawa dengan berbagai ragam dialeknya secara turuntemurun (Ismawati, 2000:3). Masyarakat Jawa bertempat tinggal di daerah Jawa Tengah dan Jawa Timur, atau berasal dari kedua daerah tersebut, sedangkan Yogyakarta dan Surakarta yang merupakan bekas kerajaan Mataram adalah pusat budaya Jawa. Masyarakat Jawa sangat menyukai kesenian. Berbagai macam jenis kesenian tumbuh subur pada komunitas masyarakat Jawa baik yang berupa seni musik/ karawitan, seni tari, seni sastra, seni pedalangan, seni teater, dan seni rupa. Berbagai jenis kesenian tersebut hidup baik di kalangan priyayi maupun rakyat jelata dan telah berurat berakar pada budaya Jawa jauh sebelum masuknya Islam di Indonesia. Semenjak Islam masuk di Jawa, pengaruh budaya Islam tidak membawa keruntuhan total tradisi Jawa yang bercorak Hindu-Jawa, bahkan terjadi interrelasi yang yang menarik di antara keduanya. Bukti-bukti terjadinya interrelasi ini bisa dilihat pada berbagai aktivitas kehidupan sehari-hari rnaupun dalam bidang kesenian.

Seni musik sebagai salah satu cabang seni adalah suatu karya yang mengungkapkan pikiran dan perasaan penciptanya melalui unsur-unsur musik seperti irama, melodi, harmoni, bentuk atau struktur lagu dan ekspresi sebagai satu kesatuan (Samidi, 1995:3). Singiran merupakan salah satu seni musik vokal yang berbentuk syair yang dilantunkan melalui sebuah lagu, baik yang berbahasa Arab ataupun Jawa sangat dikenal luas di kalangan Islam tradisionalis Jawa, terutama kalangan pesantren dan Nahdliyin (Muzakka:1994). Di masjid atau langgar-langgar Jawa singiran sering dinyanyikan setelah adzan, waktu jeda antara adzan dan iqamat, atau menunggu jamaah shalat berkumpul atau untuk menunggu seorang imam shalat datang. Singiran di masyarakat muslim Jawa juga dikenal dengan istilah puji-pujian. Munculnya singir dalam khazanah sastra Jawa, pada awalnya lebih dekat dengan syair Melayu. Darnawi mengemukakan bahwa singir sama bentuknya dengan syair dalam khazanah sastra lama yaitu terdiri atas empat baris tiap baitnya, bersajak aaaa, dan bersuku kata tetap tiap barisnya, umumnya tiap baris berisi dua belas suku kata (1964: 82). Pendapat tersebut ternyata juga diikuti Basuki (1988: 34) yang menyatakan bahwa puisi Jawa tersebut cenderung mengambil pola syair Melayu meskipun tidak seketat Makalah Kongres Bahasa Jawa IV Tahun 2006 di Semarang. Bahkan lebih tegas lagi Steenbrink menyatakan bahwa singir sebagai karya sastra Jawa jelas berasal dari syair Melayu (1988: 141). Pendapat ketiga pemerhati sastra tersebut tidak dapat dipersalahkan begitu saja, sebab pada awal munculnya dalam sastra Jawa, bentuk singir sangat dekat dengan syair Melayu.

Setiap orang tentu mengenal tentang kebudayaan.Berbagai macam kebudayaan saat ini dapat kita nikmati, baik itu kebudayaan dalam bentuk klasik, tradisional ataupun modern. Pada umumnya perkembangan teknologi dan ilmu pengetahuan selalu disertai dengan perkembangan kebudayaan, akan tetapi sering pula muncul kecendrungan adanya gejala norma-norma seni budaya yang sudah mulai terabaikan (Kayam, 1981:12).

Sebagaimana singiran yang kebanyakan berisi tentang nasihatnasihat keislaman ini telah begitu 
mengakar pada masyarakat muslim Jawa sampai dalam beberapa kasus pedagang pedagang muslim Jawa pada saat menunggu pembeli melantunkan singiran. Pada saat akan menidurkan seorang bayi kebanyakan mereka juga melantunkan shalawat yang kemudian diteruskan dengan melantunkan singiran. Hal ini kemungkinan juga dipengaruhi oleh budaya Jawa yang masyarakatnya cenderung mempunyai kesenangan untuk nembang ataupun mendengarkan tembang, seperti uraura, macapat, dan sebagainya. Menurut Aini (2019) Singiran juga bertujuan untuk memberikan nasehat serta pitutur bagi kita semua untuk selalu ingat kepada Tuhan Yang Maha Esa, sesuai dengan arti dari kata Singiran yaitu puji-pujian maka singiranpun berisi tentang puji-pujian yang ditujukan kepada Allah beserta Rassul-Nya tetapi juga berisi tentang nasehat atau pitutur saat kita telah mati dari mulai dimandikan, dikafani, dan dikuburkan.

Hal yang menarik di sini adalah tradisi singiran hanya ada dalam masyarakat muslim tradisionalis yang begitu mengakar bahkan untuk pembelajaran tatakrama dan budi pekerti anak. Namun sekarang lantunan singir-singir untuk pembelajaran budi pekerti jarang sekali dijumpai pada langgar-langgar jawa karena mungkin pengajarnya kurang sadar makna dari singir itu sendiri atau memang kurang diminati. Berangkat dari permasalahan tersebut, maka tulisan ini berusaha untuk memberikan makna dari sudut pandang penulis terhadap tradisi singiran di pesantren atau di langgarlanggar jawa.

Kehadiran singir di kalangan masyarakat santri tidak terlepas dari fungsinya sebagai sarana atau alat pembelajaran di lingkungan masyarakat santri, hingga pengajaran bahasa Arab dan berbagai cabang ilmu bahasa yang terkait. Oleh karena sangat berperannya puisi Jawa tersebut dalam proses belajar-mengajar di kalangan masyarakat santri, maka tujuan utama tulisan ini adalah mengungkap sejauh mana fungsi singir bagi masyarakat santri dan sejauh mana efektivitas karya tersebut dalam pembelajaran budi pekerti anak dalam kehidupan masyarakat.

\section{METODE PENELITIAN}

Penelitian musik vokal singiran sebagai media pembelajaran budi pekerti anak merupakan penelitian yang menggunakan pendekatan deskriptif kualitatif, dengan menerapkan konsep penelitian yang sesuai dengan kondisi di lapangan. Menurut Sugiyono (2012 : 222), dalam penelitian kualitatif yang menjadi instrument atau alat penelitian adalah penelitian itu sendiri. Oleh karena itu dalam penelitian musik vokal singiran sebagai media pembelajaran budi pekerti anak ini peneliti juga sebagai instrument yang juga harus dapat memvalidasi seberapa jauh penelitian ini.

$$
\text { Teknik pengumpulan data }
$$
merupakan langkah yang paling strategis dalam penelitian, karena tujuan utama penelitian adalah mendapatkan data. Tanpa mengetahui teknik pengumpulan data, maka peneliti tidak akan mendapatkan data yang memenuhi standar data yang ditetapkan. Oleh karena itu peneliti dalam penelitian ini menggunakan beberapa langkah dan menggunakan berbagai sumber untuk membantu proses pengumpulan data, diantaranya adalah studi observasi dan studi dokumen.

Menurut Rohadi (2011 : 182), metode observasi adalah metode yang digunakan untuk mengamati sesuatu, seseorang, suatu lingkungan, atau situasi secara tajam dalam terinci, dan 
mencatatnya secara akurat dalam beberapa cara. Metode observasi dalam penelitian seni dilaksanakan untuk memperoleh data tentang karya seni dalam suatu dan situasi yang relevan dengan masalah penelitian.

\section{HASIL DAN PEMBAHASAN}

\section{Musik Vokal Singiran}

Musik merupakan gambaran kehidupan manusia yang dinyatakan dalam bentuk bunyi yang berirama sebagai wujud pikiran dan perasaaannya. Setiap cetusan hati nurani atau daya cipta manusia dalam bentuk suara adalah suatu penjelmaan dari buah pikiran manusia yang dinyatakan dalam suatu bentuk yang bernama musik. Musik selalu mengandung keindahan dan merupakan hasil daya cipta yang bersumber pada ketinggian budi dari daya cipta yang bersumber pada ketinggian budi dari jiwa yang mengeluarkan musik itu sehingga musik selalu dijadikan tolak ukur dari tinggi rendahnya nilai-nilai dan karakter suatu bangsa (Banoe, 2016).

Teori musik menjelaskan bagaimana suara dinotasikan atau dituliskan dan bagaimana suara tersebut ditangkap dalam benak pendengarnya. Dalam musik gelombang suara biasanya dibahas tidak dalam panjang gelombangnya maupun periodenya, melainkan dalam frekuensinya. Aspekaspek dasar suara dalam musik biasanya dijelaskan dalam tala (Inggris: pitch, yaitu tinggi nada), durasi (berapa lama suara ada), intensitas, dan timbre (warna bunyi). Melodi merupakan serangkaian nada dalam waktu. Rangkaian tersebut dapat dibunyikan sendirian, yaitu tanpa iringan, atau dapat merupakan bagian dari rangkaian akord dalam waktu (biasanya merupakan rangkaian nada tertinggi dalam akord-akord tersebut). Melodi terbentuk dari sebuah rangkaian nada secara horisontal. Unit terkecil dari melodi adalah Motif. Motif adalah tiga nada atau lebih yang memiliki maksud atau makna musikal. Gabungan dari motif adalah semi frase, dan gabungan dari semi frase adalah frase (kalimat). Sebuah melodi yang paling umum biasanya terdiri dari dua semi frase yaitu kalimat tanya (antisiden) dan kalimat jawab (konsekuen).

Singiran ditulis dalam bahasa Jawa dengan huruf Arab Pegon, mengandung maksud-maksud tertentu (Muzakka:1989). Singiran yang ditulis dengan bahasa Jawa diharapkan dapat mempermudah orang-orang yang kemampuan bahasa Arab-nya kurang baik dan juga diharapkan dapat menarik muslim Jawa untuk membacanya. Beberapa materi yang berbahasa Arab dan sulit dipahami akan dapat mudah dimengerti dalam bahasa Jawa dan menarik apabila dilagukan dalam bentuk singiran. Pada akhirnya, diharapkan pembaca akan mengetahui maksud yang dikandung di dalamnya dan berusaha untuk mengamalkannya. Singiran merupakan bait-bait dan mempunyai rima tertentu dengan notasi-notasi yang bernadakan slendro. Dalam pembuatan bait-bait dalam singiran harus jelas kalimat akhirnya dan tertib urutannya. Dalam hal ini kata dalam bait-bait singiran tidak boleh terlalu panjang sehingga membosankan, dan tidak boleh terlalu pendek karena dapat membingungkan, selain itu agar mudah dihapal dan dilantunkan.

Dibawah ini contoh singiran yang dilantunkan pada saat setelah adzan dan pada acara islam seperti tahlilan, pengajian, halal bihalal :

Ya rasul salam 'alaika

Ya habib salam 'alaika 
Salawatullah 'alaika

Asyrakal badru 'alaina

Fakhtafat minhu al-buduru

Mitslu husnik ma raaina

Qathu ya wajha sururi

Contoh-contoh singiran yang berisi kaidah - kaidah budi pekerti anak, adalah sebagai berikut :

Sholatullohima lakhat kawa kip

Ngala ahmad qhoiri man rokiba najaib

Iki singir kanggo bocah lanang wadon nebihake tingkah laku engkang awon

sarto nerangake budi kang prayogo

kanggo dalan podo mlebu ing swargo

bocah iku wiwit umur pitung tahun kudu ajar toto keben ora getun

kudu tresno mring ibune kang ngrumati awit cilik marang bopo kng gemati

\section{Syair Tanpo Waton}

Astaghfirulloh Robbal

baroyaahAstaghfirulloh Minal

KhothoyahRobbi zithni

'ilmannafii'aaWawaffiqni 'Amalaan

sholikha

Ya roshulalloh salam mun'alaikaYa rofi'asyaaniwaddaarojii'Athfataiyajii rotal'alaamiYa

UuhailaljudiwalkaromiYa

Uuhailaljudiwalkaromi

Ngawiti ingsun nglara syi'iranKelawan muji pareng pengeranKang paring rohmat lan kenikmatanRino wengine tanpo pitunganRino wengine tanpo pitungan

Duh bolo konco prio wanitoOjo mung ngaji syare'at blokoGur pinter dongeng nulis lan mocoTembe mburine bakal sangsoroTembe mburine bakal sangsoro

Akeh kang apal Qur'an Hadist eSeneng Ngafirkeh marang liyaneKafir e dewe $\mathrm{Ga}^{\prime}$ di gatekkeYen isih kotor ati

akaleYen isih kotor ati akale

Gampang kabujuk Nafsu angkoroIng pepaese Gebyare ndunyoIri lan meri sugi e tonggoMulo atine peteng lan NistoMulo atine peteng lan Nisto

Ayo sedulur Jo nglale akeWajib e ngaji sak pranataneNggo ngandelake iman Tauhid eBaguse sangu mulyo matineBaguse sangu mulyo matine

Kang aran sholeh bagus atineKerono mapan sari ilmuneLaku torekot lan ma'rifateUgo hakekot manjing rasaneUgo hakekot manjing rasane

Alqur'an kodhim wahyu minulyoTanpo tinulis iso diwocolku wejangan guru waskitoDen tancep ake ing njero dodoDen tancep ake ing njero dodo

Kumantel ati lan pikiranMrasuk ing badan kabeh njeroanMukjizat rosul dadi pedomanMinongko dalan manjing e imanMinongko dalan manjing e iman

Kelawan Alloh Kang maha SuciKuduh rangkulan rino lan wengiDi tirakati di riadhoiDzikir lan suluk jo nganti laliDzikir lan suluk jo nganti lali

Urip e ayem rumongso amanDununge roso tondo yen imanSabar nerimo snajan paspasanKabeh tinakdir saking pengeranKabeh tinakdir saking pengeran

Kelawan konco dulur lan tonggoKang podo rukun ojo daksioIku sunnah e 
rosul kang mulyoNabi muhammad panutan kitoNabi muhammad panutan kito

Ayo nglakoni sekabeaneAlloh kang bakal ngangkat drajateSenajan ashor toto dhohireAnanging mulyo makom drajat eAnanging mulyo makom drajat e

Lamun palastro ing pungkasaneOra kesasar roh lan sukmaneDen gadang Alloh syuargo manggoneUtuh mayite ugo ulesUtuh mayite ugo ules Ya roshulalloh salam mun'alaikaYa rofi'asyaaniwaddaarojii'Athfataiyajii rotal'alaamiYa

UuhailaljudiwalkaromiYa

Uuhailaljudiwalkaromi

\section{Kidung Wahyu Kolosebo}

Rumekso ingsun laku nisto ngoyo woro

Kujaga diri dari perbuatan nista dan sesuka hati

Kelawan mekak howo, howo kang dur angkoro

Dengan mengendalikan hawa, hawa nafsu angkara

Senadyan setan gentayangan, tansah gawe rubeda

Meski setan bergentayangan, selalu membuat gangguan

Hinggo pupusing jaman

Sampai akhir zaman

***

Hameteg ingsun nyirep geni wiso murko

Sekuat tenaga saya memadamkan api, bisanya kemurkaan

Maper hardening ponco, saben ulesing netro

Mengendalikan panca (lima) indera dalam setiap kedipan mata

Linambaran sih kawelasan, ingkang paring kamulyan
Dilandari rasa welas asih Sang

Pemberi Kemuliaan

Sang Hyang Jati Pengeran

Sang Maha Sejati Tuhan

Jiwanggo kalbu, samudro

pepuntoning laku

Bertahta di kalbu, samudera pemandu

perbuatan

Tumuju dateng Gusti, Dzat Kang

Amurbo Dumadi

Menuju kepada Tuhan, Dzat yang tidak ada asalnya

Manunggaling kawulo Gusti, krenteg ati bakal dumadi

Menyatunya hamba dengan Tuhan,

kehendak hati akan terjadi

Mukti ingsun, tanpo piranti

Saya jaya, tanpa syarat (alat)

***

Sumebyar ing sukmo madu sarining perwito

Menyebar ke jiwa madu sarinya

perwita

Maneko warno prodo, mbangun

projo sampurno

Aneka warna prada, membangun diri

yang sempurna

- Prodo adalah guratan tinta emas pada kain batik

Sengkolo tido mukso, kolobendu nyoto sirno

Kesialan pasti musnah, musibah

matapetaka nyata hilang

Tyasing roso mardiko ...

Timbullah rasa merdeka atau bebas

Mugiyo den sedyo pusoko

Kalimosodo

Semoga dengan ucapan pusaka kalimat syahadat

Yekti dadi mustiko, sajeroning jiwo rogo

Benar-benar jadi mustika di dalam jiwa raga

Bejo mulyo waskito, digdoyo bowo

leksono

Beruntung mulia waskita, digdaya dan

berwibawa 
Byar manjing sigro-sigro

Byar terwujud gilang-gemilang

Ampuh sepuh wutuh, tan keno iso paneluh

Sakti tua utuh, tidak bisa disantet

(diteluh)

Gagah bungah sumringah, ndadar

ing wayah-wayah

Gagah riang gembira, merekah di

sepanjang waktu

Satriyo toto sembodo, Wirotomo

katon sewu kartiko

Kesatria tata sembara, wiratama

seperti seribu bintang

Kataman wahyu ... Kolosebo

Tertimpa (mendapatkan) wahyu

kalaseba

***

Memuji ingsun kanthi suwito

linuhung

Saya memuji dengan menghadap maha

tinggi

Segoro gando arum, suhrep dupo

kumelun

Laut berbau harum seperti dupa

semerbak

Tinulah niat ingsun, hangidung sabdo kang luhur

Mengolah niat saya, mengidung

(melantunkan) sabda (kata-kata) yang

luhur

Titahing Sang Hyang Agung

Perintahnya Sang Maha Agung

Rembesing tresno, tondho luhing

netro roso

Merembesnya kasih sayang, pertanda

air mata rasa

Roso rasaning ati, kadyo tirto kang suci

Rasa perasaan hati, seperti air yang suci

Kawistoro jopo montro, kondang dadi pepadang

Diwujudkan japa mantra, hebat jadi penerang

Palilahing Sang Hyang Wenang

Ridhonya Sang Maha Berwenang
Nowo dewo jawoto, tali santiko bawono

Sembilan wujud dewa, tali kekuatan

dunia (semesta)

Prasido sidhikoro, ing sasono

asmoroloyo

Abadi memuji di singgasana surga

Sri Narendro Kolosebo, winisudo ing gegono

Sang Raja Kolosebo, diwisuda di

angkasa

Datan gingsir ... sewu warso

Tidak akan tenggelam (lengser) ... seribu tahun

Dari contoh-contoh singiran di atas terlihat bahwa para pengarang berusaha untuk membuat bait bait singiran dalam format-format tertentu agar memiliki nilai keindahan, baik dari bahasanya atau struktur baitnya. Meskipun mereka menekankan kepada keindahan, tetepi mereka tidak melupakan inti dari dibentuknya singiran, yaitu maksud yang jelas dan bahasa yang sederhana dan mudah dimengerti tanpa harus berbelit-belit.

Sebagai puisi Jawa baru, singir juga memilki perbedaan yang sangat signifikan dibandingkan dengan puisi Jawa baru yang lain seperti tembang macapat, parikan, maupun geguritan. Tembang macapat memiliki ikatan dan struktur yang amat rumit. Jenis puisi ini amat terikat oleh aturan guru lagu (patokan bunyi akhir), guru wilangan (jumlah suku kata tiap baris), jumlah gatra (baris sajak), serta harus mempertimbangkan purwakanti guru swara (persamaan bunyi atau sajak), dan purwakanti guru sastra (persamaan huruf mati atau sajak rangka). Di samping itu, jenis tembang amat beragam dan masing-masing tembang memiliki patokan guru lagu, guru wilangan, jumlah gatra dan karakter psikologis yang berbeda pula (Darnawi, 1964: 13-15). Kondisi semacam itu 
tidak ditemukan dalam singir meskipun ikatan jumlah suku kata, persajakan, maupun jumlah baris tiap bait mengikatnya.

Bentuk dalam dan bentuk luar parikan pun berbeda dengan singir. Struktur parikan menyerupai pantun atau karmina. Perbedaan itu menyangkut masalah struktur dan persajakan. Lebih-lebih lagi sikap, nada, tujuan, dan isinya pun jauh berbeda. Jumlah baris parikan dua atau empat buah, separuh baris pertama berupa sampiran dan separuh baris kedua Makalah Kongres Bahasa Jawa IV Tahun 2006 di Semarang berikutnya berupa isi; jumlah suku kata tiap baris parikan terdiri atas 4 sampai 8 suku kata dan bersajak selang-seling (abab). Parikan dapat diciptakan secara spontan dalam bentuk lisan untuk mengungkapkan perasaan tertentu seperti pelukisan perasaan asmara, sindiran atau lelucon. Adapun singir tidak dapat diciptakan secara spontan sebab singir biasa dipergunakan untuk mengungkapkan cerita atau menguraikan ajaran agama Islam. Hal itu berarti bahwa bait-bait singir berhubungan erat satu dengan yang lain tidak seperti parikan yang tujuan dan isinya sudah tampak pada satuan baitnya. Geguritan pun mempunyai perbedaan yang amat menonjol dibandingkan singir sebab geguritan biasa diucapkan seperti orang berbicara, biasanya berisi sindiran keadaan masyarakat suatu waktu serta mengandung unsur pendidikan (Darnawi, 1964: 53).

Meskipun pada tahap awal munculnya puisi tersebut tampak seperti puisi terikat, tetapi dalam perkembangannya mulai dari geguritan yang muncul pada zaman Jepang hingga sekarang ini puisi tersebut menyerupai puisi bebas seperti puisi Indonesia modern yang tidak terikat oleh jumlah suku kata, baris, bait, dan persajakan. Hal itu menunjukkan bahwa dari segi struktur formalnya, geguritan jauh berbeda dengan singir. Begitu juga dari dari segi isi atau materi yang dikandungnya, ekspresi individual pengarang tampak lebih menonjol (bdk Dojosantosa, 1986: 87-118).

Apabila dilihat dari bentuk penyajiannya singiran adalah musik vokal, yang disajikan tanpa mempergunakan instrumen apapun juga, bahkan tidak menggunakan nada dasar tertentu (Aini, 2019).

\section{Singiran dalam masyarakat santri}

Materi dari singiran biasanya berupa Shalawat Nabi, nasihat-nasihat keagamaan atau terjemah. Tiga fungsi utama singir, yaitu fungsi hiburan, fungsi pendidikan dan pengajaran, dan fungsi spiritual (Muzakka:1989). Fungsi hiburan muncul karena hadirnya singir dalam khazanah sastra selalu dinyanyikan baik dengan iringan musik tertentu maupun tidak. Fungsi pendidikan dan pengajaran muncul karena di samping singir mengekspresikan nilai-nilai keislaman, singir juga digunakan sebagai bahan ajar dan atau media pengajaran di kalangan masyarakat santri. Fungsi spiritual muncul karena sebagian besar singir diberlakukan penggunaanya semata-mata sebagai upaya penghambaan diri (ibadah) kepada Tuhan yakni untuk mempertebal rasa keimanan dan ketakwaan. Ketiga fungsi tersebut sangat berkait erat sehingga sulit untuk dipisahkan satu dengan yang lain, sebab bagi pendukungnya singir memberikan spirit untuk beribadah dan memberikan ilmu pengetahuan dengan cara yang sangat menyenangkan.

Singiran biasanya diberikan oleh kiai dalam acara pengajian yang kemudian meminta para jamaah untuk menghapalkan. Selanjutnya, kiai akan 
menjelaskan dengan detil maksudmaksud yang terkandung dalam singiran itu, dengan harapan jamaah akan mengetahui dan dapat mengamalkan dalam kehidupan mereka. Untuk selalu mengingat terhadap singiran dan dapat didengar oleh orang banyak, maka disarankan untuk melantunkan singiran tersebut pada waktu antara adzan dan iqamah dalam masjid.

Selain itu, juga dapat menghindari kegiatan bercakap-cakap atau bermain di dalam masjid pada saat menunggu imam dalam melaksanakan shalat berjamaah. Singiran telah menstimulasi bagi munculnya kreativitas dalam ekspresi seni masyarakat Islam Jawa. Singiran biasanya dibawakan dalam acara kultural seperti mauludan, manakiban, yasinan, tahlilan, bahkan khaul (Mashad, 2019).

Singiran yang didendangkan biasanya yang telah popular seperti lir ilir, shalawat, dan makna Jawanya. Singiran dengan apapun kritik yang dilontarkan terhadapnya ternyata mampu diserap dan dinternalisasikan, bahkan dapat memunculkan kultur baru dan kreativitas seni dalam masyarakat Islam Jawa. Akan tetapi, yang perlu disadari adalah tidak adanya sebuah pendekatan yang akan selalu cocok untuk ruang dan waktu yang berbeda dalam pembelajaran Islam.

\section{Antropologi dalam Teknologi Pembelajaran}

Antropologi seni hendaknya melihat seni sebagai produk karya yang merupakan hasil dari proses teknis yang dikuasai oleh seseorang dalam suatu masyarakat sebagai seniman. Perhatian Antropologi Seni terutama mengkaji kemampuan dan kemahiran seniman dalam menuangkan gagasannya melalui media menjadi suatu produk karya seni, yang baik indah ataupun tidak, adalah menjadi bagian dari satu kesatuan kegiatan dalam masyarakatnya. Ada tiga unsur yang terdapat dalam seni secara umum: unsur karya, unsur seniman dan unsur publik seni. Ketiganya saling berkait dalam satu kesatuan di dalam konteks tertentu. Unsur benda seni (karya) merupakan bagian kajian utama dari estetika: persoalan kebentukan, dan persoalan indah-tak indahnya karya tersebut.

Meskipun demikian, unsur karya seni sebagai sebuah produk yang mewujud dalam bentuk tertentu juga menjadi penting adanya dalam antropologi seni, sebab ia menjadi penanda awal dimungkinkannya kelanjutan proses pengkajian dan analisa dalam suatu penelitian bagi para antropolog terhadap seniman sebagai pencipta karya tersebut. Unsur yang kedua adalah publik seni,yaitu sekumpulan orang yang, baik secara khusus ataupun tidak, 'mengkonsumsi' karya seni. Unsur ini merupakan bagian kajian utama dari sosiologi (seni). Tetapi bagaimanapun unsur publik juga secara tak langsung menjadi aspek lain yang diperhatikan para antropolog dalam penelitiannya. Publik seni, adalah unsur yang kemudian menerima, mengapresiasi bahkan memesan suatu karya yang diciptakan oleh seniman. Dengan demikian ia sedikit-banyak memberi pengaruh bagi seniman dalam mencipta karya, sehingga menjadi relevan pula dalam kajian antropologi seni. Unsur yang ketiga adalah seniman. Ia adalah pencipta karya seni yang baik diterima ataupun tidak oleh masyarakatnya, karya ciptaannya tersebut merupakan bagian dari produk sosial juga, yang sedikit-banyak dipengaruhi lingkungan serta masyarakatnya. Unsur seniman merupakan kajian utama dalam antropologi seni, yang tentu saja 
kaitannya dengan karya seni yang diciptakannya. Ketiga unsur seni yang tersebut di atas merupakan unsur-unsur terpenting yang menjadi perhatian antropolog dalam penelitiannya. Hanya saja perbandingannya tentu berbedabeda bergantung pada tujuan dan kepentingan si peneliti dalam penelitian. Hal lain yang juga penting diperhatikan dalam sebuah penelitian antropologi seni adalah unsur konteks, yaitu persoalan kapan dan dimana objek penelitian muncul dan berada, serta kapan dan dimana peneliti seharusnya melakukan kajian yang tepat. Kebanyakan kajian antropologi seni adalah tentang seni pra-moderen, sebab seni tersebut dianggap konvensional dan sukar berubah. Dengan demikian maka diharapkan bahwa pola-pola yang tetap pada seni dalam suatu masyarakat dapat mudah dijabarkan dalam perkembangan teknologi di masyarakat.

\section{Singiran sebagai media pembelajaran Budi Pekerti}

Fungsi singir yang paling menonjol bagi masyarakat pendukungnya adalah diberlakukannya singir sebagai media pendidikan dan pengajaran. Hampir seluruh pesantren, madrasah, dan balai pengajian di kalangan masyarakat santri tradisional memanfaatkan bentuk sastra tersebut baik untuk pendidikan nilai-nilai agama maupun pengajaran ilmu-ilmu lain. Pemanfaatan singir sebagai pendidikan nilai-nilai agama tampak pada muatan materinya yang berkaitan erat dengan penanaman keimanan, keislaman, dan moralitas anak. Sedangkan singir sebagai media pembelajaran tampak pada pemakaian sejumlah singir sebagai buku ajar/ buku teks dalam proses pendidikan kaum santri serta banyaknya penulisan berbagai materi keilmuan pesantren terutama akhlaq, fiqih, kisah/sejarah Islam.

Penggunaan bentuk singir juga efektif digunakan untuk pembelajaran materi keilmuan di Madrasah Diniyyah dan pondok pesantren, terutama pengajaran tata bahasa Arab dalam bentuk puisi yang dilagukan. Puisi tersebut dipandang sangat membantu dalam menghafalkan kaidah kaidah bahasa Arab karena bait-bait puisi tersebut mudah dihafalkan dan sangat menyenangkan bila dinyanyikan baik secara individual maupun kolektif. Pendeknya, para santri belajar bahasa Arab dengan menyanyikan bait-bait singir atau mereka bermaksud menyanyikan bait-bait singir sambil menghafal kaidah-kaidah bahsa Arab.

Singir sangat efektif untuk pembelajaran kaidah-kaidah budi perkerti yang bagi para anak santri, bentuk syair puisi yang menggambarkan budi perkerti seorang anak yang baik tersebut akan lebih efektif lagi diselingi untuk pembelajaran materi keilmuan pada anak santri. Namun, sayang sekali pemanfaatan singir hingga saat ini belum optimal. Madrasah, maupun pesantren tidak banyak menggunakan naskah-naskah dan atau teks-teks singir dalam pembelajaran beragam ilmu tentang tata krama, keislaman, keimanan, dan lain-lain meskipun cukup banyak naskah dan teks singir. Oleh karena itu, dalam tulisan ini penulis menawarkan pemanfaatan bentuk singir sebagai media pembelajaran budi pekerti pada anak.

Pemanfaatan singir budi perketi di pesantren tidak hanya didasarkan pada tingkatan usia saja, tetapi bisa juga didasarkan pada tingkatan kemampuan pengetahuannya terhadap agama Islam. Santri pemula menurut tingkatan usia berkisar antara 7-15 tahun yaitu tingkatan bagi para santri 
yang duduk di Madrasah Ibtidaiyah/ Awwaliyah dan Tsanawiyyah/ Wustho (setingkat usia SD dan SLTP). Hal ini selain pembelajaran kemampuan pengetahuan adalah santri yang sama sekali atau belum banyak pengetahuannya tentang keimanan, keislaman, dan pada umumnya mereka belum pandai atau belum lancar membaca Alquran serta menguasai baca-tulis Arab.

Fase usia tersebut adalah fase keemasan dalam belajar karena di samping pikiran dan otaknya sedang cemerlang, mereka juga sedang giatgiatnya mencari ilmu pengetahuan sebagai akibat dari motivasi eksternal yang pada umumnya berasal dari orang tuanya khususnya pembelajaran budi pekerti. Jika pada usia ini, para ustad (guru madrasah) atau kiai mengajarkan beragam ilmu keimanan dan keislaman dengan menggunakan naskah/ teks singir yang ada atau menuliskan beragam pengetahuan tersebut dalam bentuk singir, dapat dipastikan mereka akan lebih tertarik untuk mengaji dan belajar di madrasah atau pesantren karena mereka dapat memahami materi yang ada dengan cukup menyenangkan melalui lantunan bait-bait singir tersebut.

Langkah awal untuk melakukan pembelajaran alternatif ini, para ustad/guru madrasah atau kiai dituntut untuk melakukan inventarisasi sejumlah singir yang berkembang di kalangan masyarakat kemudian memilah dan mengelompokkannya dalam berbagai cabang ilmu. Proses pembelajaran dilakukan per pokok bahasan atau subpokok bahasan dengan cara mengambil bait-bait singir yang sesuai. Pada tahap awal ustad atau kiai memberi contoh dengan cara menyanyikan bait-bait puisi dengan irama tertentu, diupayakan dapat memilih irama yang merdu, kemudian para santri menirukan bunyi bait-bait puisi tersebut dengan irama yang sama. Selanjutnya, ustad atau kiai memberikan penjelasan materi pokok bahasan.

Tahapan lanjutan yang harus dilakukan oleh pemakai metode pembelajaran karena belajar akan dapat ditingkatkan juga oleh pengaruh faktor dari luar. Misalnya dengan menggunakan media atau model dalam proses pembelajaran (Soeparno 1998 : 10). Pertama, ustad/ guru dituntut kreativitasnya, yaitu berlatih menyenandungkan atau menyanyikan bait-bait singir dengan irama merdu dan bervariasi sehingga tidak terkesan monoton dan membosankan para santrinya. Selanjutnya anak disuruh menirukan lagu yang telah dicontohkan oleh kiai/ ustad/ guru. Dengan menggunakan metode pembelajaran semacam itu bisa diprediksikan bahwa pembelajaran materi-materi keislaman, keimanan dan tata karma di kalangan anak santri akan lebih menarik dan lebih hidup sebab para anak santri terlibat langsung dalam proses pembelajaran, tidak semata-mata menjadi pendengar yang patuh dan setia.

\section{SIMPULAN}

Dari uraian di atas dapat ditarik simpulan, bahwa singir yang telah terabaikan dari masyarakat, ternyata mempunyai fungsi yang sangat bermakna bagi pendukungnya yaitu dimanfaatkannya sejumlah singir dalam pembelajaran budi pekerti anak. Dengan adanya bentuk singir budi perkrti anak akan merasa lebih paham karena mereka merasa terlibat dalam pembelajaran sekaligus dapat menikmati dan menyanyikan irama bait-bait singir dengan indah. Dengan adanya pandangan terhadap fungsi kesenian singir seharusnya para 
pendidik khususnya seni harus lebih kreatif lagi dalam inovasi tentang pendidikan melalui media kesenian. Sebagai akademisi seni sebaiknya selalu melestarikan dan merekontruksi untuk kemajuan kesenian dan harus selalu mengkaji makna dan ilmu seni tradisional kita agar kesenian kita selalu terjaga kemurniannya dan dapat terus berkembang sehingga anak cucu kita bisa menikmati hasil - hasil seni tanpa ada keraguan ilmu kesenian yang diterapkan.

\section{DAFTAR RUJUKAN}

Aini, Rohmah.2019. Sinkretisme dalam Tradisi Seni Musik Tradisional Jenengan sebagai Identitas Masyarakat Islam Jawa di Desa Kesugihan Kecamatan Kesugihan Cilacap Jawa Tengah. Thesis tidak diterbitkan. Bandung: UIN Sunan Gunung Djati.

Basuki, Anhari.1988. Salah Satu Sisi dalam Sastra Pesantresn dalam Widya Parwa No. 32, April 1988.

Banoe, Pono.2003. Pengantar Pengetahuan Harmoni. Yogyakarta. Kanisius.

Kayam, Umar.1981. Seni, Tradisi, Masyarakat. Jakartya: Sinar Harapan.

Mashad, Dhurorudin.2019. Menelaah Sisi Historis Shalawat Badar:Dimensi Politik Dalam Sastra Lisan Pesantren. Jurnal Penelitian Politik Vol.16, No.1, Juni 2019.
Muzakka, Moh.1989. Analisis Struktur Syair Paras Nabi. Semarang: Skripsi Fakultas Sastra Undip.

Sunopratomo, Samidi.1955. Evolusi Musik. Yogyakarta: Pusat Musik Liturgi.

Shadry, Abd. Rauf.1980. Nilai Pengajaran Bahasa Arab dan Sejarah Perkembangannya. Bandung: Bina Cipta.

Steenbrink, Karel.A.1988. Mencari Tuhan dari Kacamata Barat: Kajian Kritis Mengenai Agama di Indonesia. Yogyakarta: IAIN Sunan Kalijaga Press. 